\title{
Water in the Anthropocene: Perspectives on Poetry by South African Women
}

\author{
Deirdre Cassandra Byrne ${ }^{1 *}$
}

Published: March 5, 2021

\begin{abstract}
Cape Town's drought (2015-2017) focused attention on humans' dependency on water and the irreversibility of environmental degradation in South Africa in the Anthropocene. Water is symbolically linked to femininity as fluid, connected to the moon and tides, generative and sustaining. This article explores South African women poets' diverse responses to water, focusing on Allison Claire Hoskins, Toni Stuart, Koleka Putuma, Wilma Stockenström and Gabeba Baderoon. Feminist psychoanalysis, feminist new materialism and decolonial theory are brought to bear in the analysis. The audio-visual poems by Hoskins and Stuart feature water as an irresistible force of change and retribution. Similarly, Putuma's celebrated poem 'Water' accuses colonisers of using water to facilitate their agenda. She pleads for water to be restored as a site of memory for black people. Stockenström's (2007) The Wisdom of Water draws on traditional nature poetry. She represents water as filled with life, giving life, and deeply connected to women. Gabeba Baderoon is the only poet to write about the environmental degradation brought about by climate change. The article concludes that the poets' diverse strategies in their representation of water intersect in their portrayal of it as symbol and medium of connection.
\end{abstract}

Keywords: South African women's poetry, water in poetry, multimodal poetry, decolonising poetry, water as relationship

\section{INTRODUCTION}

Water is polyvalent and multifaceted, playing numerous roles in the Earth's biosphere, in social existence and in human culture. Carbon-based life on Earth is dependent on the simple compound of oxygen and hydrogen that dissolves nutrients, so that they can pass from the environment into the organism, and removes waste products. Water is similarly necessary for social and economic development: most cities are built near large freshwater sources, which supply the population's needs for sanitation, drinking and cooking, and offer convenient transport routes. Water holds gendered implications for human socio-economic existence and for symbolic communication. Water is associated with household and family socio-economic security. Across cultures, women bear most of the responsibility to provide water for families to drink, eat and use for cleaning. This is due to women's socially assigned nurturing roles and stereotypes that relegate household labour to 'women's work'. Water also holds metaphysical associations with the spiritual and the sacred. Many rivers are venerated as life-giving and life-saving deities and as the source of life. In view of its myriad resonances, Wendy Jepson et al. (2017:14) comment that 'By reconceptualizing water as a relationship, we are better able to incorporate the interconnectedness of water rights and water responsibilities as core to water security'. Jepson et al. provide an apt focus for my article, which analyses the representation of water in poetry by South African women. I explore poetry from Wilma Stockenström's The Wisdom of Water, as well as from Koleka Putuma's celebrated Collective Amnesia, Gabeba Baderoon's The History of Intimacy, Joan Metelerkamp's Making Way (2020) and audio-visual poetry such as Toni Stuart's 'Krotoa Eva speaks: a cape jazz poem in three movements'1 (2018) and Allison Claire Hoskins' 'We are Coming for Everything' (2018).

Many South African women poets, whose gender is associated with water in myth, symbolism and popular media, write about water. This is not to suggest that male poets cannot or do not write about water: to take only one example, Pieter Odendaal's 2018 collection of poetry, asof geen berge ooit bier gewoon het nie ('as though no

${ }^{1}$ I am following the poet's capitalisation here. 
mountains ever lived here'), ${ }^{2}$ includes poems about the ocean, rain and the river that runs through his home town of Stellenbosch. The first poem in the collection, 'die aand toe die see gesing het' ('the evening when the sea sang') ${ }^{3}$ features an epigraph from Putuma's 'Water', signalling his awareness of poetry by women. Similarly, I do not wish to claim that there is a single aesthetic that women poets use when writing about water: rather, I foreground the diversity of creative strategies that they employ. Surprisingly, most women poets do not write directly about environmental degradation, a theme that appears, of all the poems I discuss in this article, only in Baderoon's writing. Nevertheless, by paying attention to the representation of water as relationship, the connection between all planetary life can be illumined and shed light on our shared predicament in the Anthropocene.

Defining the Anthropocene and situating poetry in relation to it is tricky. Paul J. Crutzen and Eugene F. Stoermer (2000) proposed the term as a replacement for 'Holocene'. The term signals scientists' growing realisation that humans' impact on the geo-biological systems that make up the Earth could no longer be ignored or reversed. Nevertheless, some theorists have chosen to use other terms: possibly the greatest proliferation is in Donna Haraway's article 'Anthropocene, Capitalocene, Plantationocene, Chthulucene: Making Kin' (2015). Haraway proposes a plurality of terms in recognition of the rapid changes and diverse phenomena that are being seen in the current era. None of Haraway's list of terms has gained much traction besides the Anthropocene, possibly because it mobilises the realisation that human actions have caused climate change and environmental degradation. Nevertheless, the concept of the Anthropocene encodes tensions and inequalities. Climate change does not affect men and women equally; women are overwhelmingly responsible for food and water security, so environmental damage impacts on them in greater measure. There are also class inequalities: whilst the planet sustains and nourishes all its life-forms, those with greater resources at their disposal tend to use them to the detriment and even exclusion of those who have less. Finally, even the idea that we are in an era where humans have had a decisive impact on the earth's condition and prospects cannot be taken for granted: some thinkers question and even deny it. Most scientists accept the terminology, though, and with it, the notion of environmental degradation caused by human intervention. This is clearly seen in the condition of the planet's water resources, as Vandana Shiva (2015: 23) observes:

Disregard for the limits of nature's hydrological cycle meant that rivers could be drained and polluted by mining waste. Disregard for the natural rights of others meant that people were denied access to water, and regimes of unequal and nonsustainable water use and water-wasteful agriculture spread ...

In the light of water's protean, mutable nature and the multiple ways it has been perceived and represented in art and culture, I draw on three different theoretical approaches to gender and water: feminist psychoanalysis, feminist new materialism and decolonial theory. Feminist psychoanalytic theory, represented by the work of Julia Kristeva, illuminates the connections between women and water through an understanding of women's bodies as 'leaky' and prone to discharge fluids such as blood, milk and tears. Kristeva (1985: 143) perceptively notes that 'milk and tears have in common (...) that both are metaphors of non-language, of a 'semiotic' that does not coincide with linguistic communication'. The Kristevan semiotic is the pre-linguistic realm inhabited by the subject before individuation and before insertion into the symbolic. Fluids that issue from a woman's body (blood, milk and tears) are venerated, even fetishised, in many cultures, as Melissa Meyer (2005: 2) observes:

Mary Douglas [in Purity and Danger: An Analysis of Concepts of Pollution and Taboo] argued that 'the powers and dangers credited to social structures' were transposed onto the body, as a symbol of society. Cognitive psychologists showed how bodily orifices tend to be perceived as vulnerable, marginal zones that symbolize the boundaries between internal purity and external danger. Humans invested substances that transgressed these boundaries, such as blood, semen, saliva, tears, urine and feces, with powerful properties.

Women's bodies are strongly associated with blood (via menstruation); milk (signalling their capacity for motherhood); and tears (physiological signs of emotion). Their psyches are perceived as mutable because they are supposedly more susceptible to emotion than men. Women tend to be perceived as physiologically and psychologically fluid and watery. Poetic representations attest to this association.

Feminist new materialism, deriving largely from the work of Karen Barad (2003; 2007), contributes valuable insights into creative knowledges of water by refocusing attention on the material and relational aspects of existence (cf. Parikka, 2015: 49). Barad argues that representationalism has privileged discourse at the expense of matter and that an understanding of phenomena as performative, entangled, agential and material can help to remedy this disproportionate emphasis. Although poetry is strongly dependent on discourse, there are, following Barad, different levels of objectifying and essentialising the nonhuman natural world in the genre. Poetry that emphasises

\footnotetext{
${ }^{2}$ I am following the poet's capitalisation here.
}

3 All translations from Afrikaans are my own. 
the importance of relational ontology and ethics, and that does not reify the observer as privileged possessor and creator of knowledge, is easier to read from a new materialist perspective. Of particular relevance for my argument here is Stacy Alaimo's discussion (2008: 302), in her provocatively titled article, 'Ecofeminism without Nature? Questioning the Relation between Feminism and Environmentalism' of the dangers of essentialising or backgrounding 'nature.' She warns that

(...) nature (...) can no longer serve as the ground of essentialism, because it is no longer the repository of unchanging truths or determining substances but is itself an active, transforming, signifying, material force.

This is an apt reminder that poems about water are not about a substantial entity, but a phenomenon (or phenomena) in the process of becoming, which co-constitutes observers, poets and other human users.

Water evokes particularly painful experiences in African history as the medium of the Middle Passage across the ocean from Africa to the Americas, which took between 9 and 11 million Africans forcibly into slavery. In addition, European colonisers (mainly from Britain and The Netherlands) were borne by water to Africa. Upon arrival, they relegated the people whom they found living in Africa to less-than-human status. Nelson MaldonadoTorres (2007: 245-246) explains this in epistemological terms:

The very relationship between colonizer and colonized provided a new model to understand the relationship between the soul or mind and the body; and likewise, modern articulations of the mind/body are used as models to conceive the colonizer/colonized relation, as well as the relation between man and woman, particularly the woman of color.

The humanity of the colonised ('particularly the woman of color [sic]') is discursively, ideologically and legally negated by coloniality. This leads to Franz Fanon's provocative announcement in Black Skin, White Masks that 'the black is not a man' (1986: 11). Undoing the negation of the humanity of the colonised that is at the heart of coloniality, Maldonado-Torres (2007: 261) suggests, requires:

(...) a confrontation with the racial, gender, and sexual hierarchies that were put in place or strengthened by European modernity as it colonized and enslaved populations through the world.

Other decolonial theorists have written about the necessity of 'delinking' from the logic of coloniality, including the hierarchy of human/nonhuman, European centre/colonial periphery, and others in order to bring to the fore 'other epistemologies, other principles of knowing and understanding and, consequently, other economy, other politics, other ethics' (Mignolo, 2007: 453). Ramón Grosfoguel (2006: 168 and 170) argues that decolonisation entails moving 'the locus of enunciation' from the situation of the coloniser to that of the colonised. The insights provided by these thinkers enable me to approach poetry by Hoskins, Stuart and Putuma as skilful and multimodal delinking from Eurocentric thinking, particularly about black people's relationships with the natural world. Seen as a recurring and significant theme, water serves, in these poems, to interweave and connect social and creative constructions, personal and political concerns, colonial and decolonial epistemologies.

\section{'SPOKEN WORD’ VERSUS 'PUBLISHED POETRY’ IN SOUTH AFRICA}

South Africa has a vibrant spoken word poetry scene, which has witnessed artists such as Toni Stuart, Malika Ndlovu, Bella Cox, Allison Claire Hoskins and Vangile Gantsho curating, choreographing and performing poems about water, among other themes. ${ }^{4}$ The spoken word scene is separate, politically and affectively, from poetry publication, with overtones of colonial and racial discrimination between spoken word ('stage') and published ('page') poets. Poetry publishing in the country is fraught with racial and class inequalities, as poets who possess financial resources - often, white poets - are able to fund the publication of collections that are assumed to have only a small readership. Exploring this racial differential, Raphael d'Abdon (2018: 50) asserts that the distinction between 'performance poets' and 'published poets' 'continues to consider black poetry as having a lesser literary value while situating it on the margins of a lettered world configured by largely Eurocentric views'. D'Abdon rightly exposes white, neo-colonial literary critics' distinction between 'spoken word' and 'published' poetry. Published poetry, often written by white poets, receives accolades and is prescribed for study, while spoken word poetry is celebrated by popular audiences at mass gatherings, is not always recorded or publicised, and does not receive the attention of the country's literary elite. In poetic praxis, though, there is often an overlap between

4 See, for example, Malika Ndlovu's performance on Kenyan streaming service Paza Sauti (https://www.youtube.com/watch?v=FFZSTVmDUcU), which begins 'I return to the water / I return to the sea / We return to our mother / Return with me' (2020).

(C) 2021 by Author/s 
spoken word and published poetry, with many poets using both modes, so that there is no difference between performance poetry and poetry per se. In fact, the audio-visual poems discussed in this article draw on a wider range of semiotic strategies than are available to poetry that is available only in published form. The multimodal affordances of spoken word poetry, including body language, visual imagery, musical accompaniment, voice and intonation, furnish a depth of meaning that is often not accessible via the page.

Allison Claire Hoskins' poem 'We are Coming for Everything' (2018) announces that 'we' black people are 'coming' to take back what has been taken away by colonialism. Colonisers are figured in the poem as 'wicked hands' that 'break erase dictate' and have taken away the very selfhood of black people. Significantly, Hoskins invokes the power of water in the poem's opening stanza, which threatens:

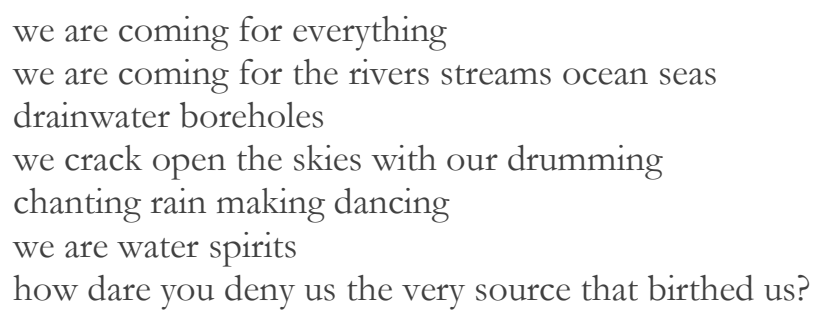

Black people, joining forces to take back the source and energy that sustains life, are likened to the irresistible power of water both to connect and to change. The 'water spirits' of the sixth line are nurturing and comforting, promising to sustain life, but they are also vengeful. They draw on a wealth of indigenous knowledge about inkanyamba, the snake in the sky or tornado, which can wreak havoc in anger at being separated from its partner (Wood, 2000).

In a similar vein to Hoskins, Toni Stuart's audio-visual poem, 'Krotoa Eva's Suite: a cape jazz poem in three movements' (2018) decolonises South African history by surfacing the life of a woman who played a central role in the early colonial project. Krotoa was her Khoi name, but she was renamed 'Eva' when she was taken into slavery in the home of Jan van Riebeeck, the first Governor of the Cape of Good Hope. Krotoa Eva served as a translator in Dutch, Khoi and Portuguese and married a Dutch settler, but was later disowned by Khoi and Dutch alike; she died alone, aged 39, on Robben Island. Her life is both extraordinary and emblematic of settlers' disregard of indigenous people and knowledges. Throughout Stuart's poem, Krotoa Eva is repeatedly transmuted into an elemental force, often a watery one. The poem opens with the haunting line: 'My tears fell down the flanks of Devil's Peak'. Images of sunlight on an estuary filled with reeds accompany several of the early sections as Krotoa Eva speaks of her dual identity. As she comes to realise the enormity of what has been done to her, she speaks a powerful 'riff articulating her desire to be away from warring forces and men's desire for her adolescent body. The sea's might can carve a tunnel through her psychological scars to create peace: 'I wanted to break the cage of bone and flesh / smash it like wave on rock', so that she can reach 'the other part of me / where silence lives'. In a metatextual moment later in the poem, Krotoa Eva threatens:

I am the silent water burning in every woman of this land

I am the spent wave receding emptying the shore becoming ocean again

Beware my return

A woman's voice is the fulcrum of war ${ }^{5}$

These lines are spoken against a backdrop of a wave breaking over distant rocks and pooling on the beach. Their multimodal effect is to position Krotoa Eva, and with her, all the silenced histories of oppression and violence perpetrated against indigenous South Africans, as an irresistible, watery force of change.

\section{KOLEKA PUTUMA: DECOLONISING THE OCEAN}

In 2016, Cape Town poet Koleka Putuma released a YouTube video of her poem 'Water'. The video, edited and directed by Ecuadorian film-maker José Cardoso, shows Putuma on a rocky coast, with the sound of waves in the background, reciting her poem. The printed version of the poem forms part of Putuma's début collection, Collective Amnesia, which has enjoyed record success, having been translated into six languages and having sold more than 5000 copies. The video ensures that 'Water' exploits multiple modalities - visual, graphic, sonic, gestural and aural - to convey the use of water in coloniality's oppression of South African black people. The use of multimodality (cf. Kress, 2010; Stein, 2008) is a decolonial move, opposing the privileging of the printed word in

\footnotetext{
${ }^{5}$ There is no manuscript of this poem, so line breaks are my own.
} 
Eurocentric culture. Bibi Burger (2020: 24) draws on Meg Samuelson's work on the ocean in South African culture to arrive at a layered understanding of the way the ocean functions in recent poetry:

The ocean as metaphor for suppressed histories overlaps with the representation of the ocean as the literal site of historical events (...). The ocean as metaphor for suppressed histories also seeps into the spiritual meaning accorded to the ocean, given the centrality of ancestors in some Southern African cosmologies.

While I agree that Putuma's 'Water' draws on the ocean 'as metaphor for suppressed histories', I find the poem's focus on race to be more specific than Burger allows for. 'Us' (blacks) and 'you' (whites) are opposed by virtue of our histories, identities and racial situations (Putuma, 2017: 96-100). The poem reverses the 'dialectical antagonism between whiteness and wildness' (De Kock, 2006: 197), which Leon de Kock sees as a central justification for racist South African cultural production. In 'Water', Putuma exposes the irrationality and barbarism of white culture, including its cruelty to indigenous black South Africans and its heteropatriarchal, white male deities. The poem performs what Christina Sharpe (2016: 18) calls 'wake work': 'a mode of inhabiting and rupturing this episteme with our known lived and un/imaginable lives'. 'Water' ruptures the colonial episteme by using the ocean as a symbol for moving the locus of enunciation from the (Christian) European metropole to the situation of a queer black womxn in South Africa. As the poem progresses, the video shifts locations to a white building, which is revealed as a church, panelled and furnished in dark wood, where the speaker whispers her reservations about the Christian religion:

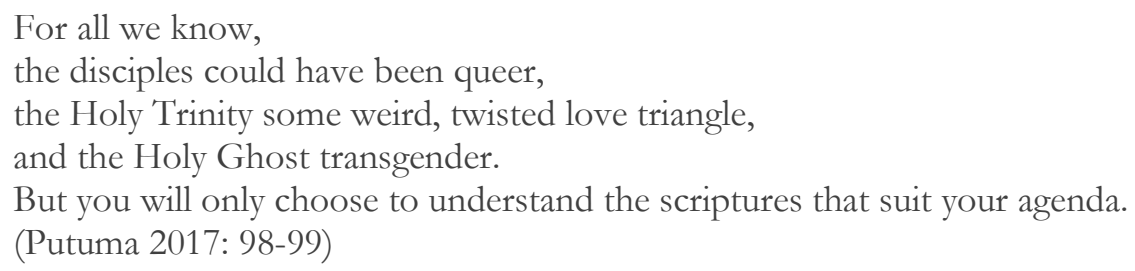

Significantly, Putuma's decolonial re/visioning takes the form of imagining the male figures around 'blue-eyed and blond-haired Jesus' (2017: 98) as gendered differently from the official account: a move that keeps gender at the centre of the poem's 'wake work'. From the interior of the church, the setting shifts to a busy street in the highly colonial centre of Cape Town, amid the daily throng of people going about their daily business, where Putuma closes the poem by confronting the audience with the reality of black people dying in South Africa:

Another one (who looks like me) died today.

Another one (who looks like me) was murdered today.

May that be the conversation at the table

and we can all thereafter wash this bitter meal with amnesia.

And go for a swim after that.

Just for fun.

Just for fun.

(Putuma, 2017: 100)

These lines resonate with multiple ironies: 'the table' recalls the Last Supper in Christian tradition, the 'bitter meal' recalls South African history where (as Putuma notes) black people were required to serve whites' food; and 'amnesia' alludes to the suppression of colonial histories, aside from its resonance with the title of the collection. The poem has disrupted the episteme of twenty-first-century South Africa, and no reader who has followed its trajectory will regard swimming as 'fun'. In this way it achieves numerous creative and ideological goals: by revisioning the ocean, Putuma also revisions racial and gender power relations in the country that she inhabits. Yet, unlike Stuart, she does not depict the ocean or water as agentive: its role in the poem is to connect black people to their colonial histories, rather than to change or create anything.

\section{WILMA STOCKENSTRÖM'S THE WISDOM OF WATER}

Wilma Stockenström's collection, The Wisdom of Water (2007), consists of a selection of her poems, translated into English. The title of the volume may be read as anthropomorphising water, but it also holds the possibility of an 'Other' consciousness, greater than the individual, and encodes an impulse towards 'remaking the world 
materially and relationally' (Hickey-Moodey and Page, 2015: 12). Tim Huisamen writes in the volume's Foreword that Stockenström's poetry articulates 'a longing to mix with that which is greater' (Stockenström, 2007: 13). This is a standard description of a common poetic response to the dialectic between self and universe. Huisamen's comment reads Stockenström within the constructivist tradition as a poet writing about something or writing on a theme, a notion that places the poet in the position of a knowing self, commanding and disseminating knowledge about the theme or object of poetic enquiry. Instead of reading Stockenström's poetry in this way, I perceive a less human-centred approach and a less stable knowing self in her poetry. The mutability of water, its capacity to infiltrate cracks and to cross boundaries, allows Stockenström to exploit the entanglement of the human and nonhuman and to create the world around her - a world founded on water and water use - as co-emergent with the human. A new materialist reading of her poetry coincides with Kristeva's (1998: 29) understanding of poetic language as an apt vehicle for exploring the function of significance because 'To describe the signifying operation of poetic language is to describe the mechanism of conjunction within a potential infinity'. This formulation sees all poetry as constituted through conjunction with a greater whole, strongly recalling Huisamen's description of Stockenström's writing, but avoids the apparatus of poet, prosody and theme that characterises his views.

It would be typical of presumptuous anthropocentric thinking to use poetry to speak for water, or imaginatively ventriloquise the voice of the element. Likewise, speaking about water could fall into the trap of quasi-objectivity, which relies, again, on belief in the exceptionalism of the scientist. My view is that Stockenström's poetry about water, in the words of Vietnamese film-maker Trinh T. Minh-Ha (Chen 1992: 87), 'speaks nearby' natural elements such as water. 'Speaking nearby' is a halfway position between 'speaking for' and 'speaking to.' It neither co-opts nor ventriloquises the subject: it is 'a speaking that does not objectify, does not point to an object as if it is distant from the speaking subject or absent from the speaking place' (Chen 1992: 87). By 'speaking nearby' water, Stockenström avoids Castro-Gomez's (cited in Grosfoguel, 2006: 168) 'point zero': the illusion that the perceiving self is nowhere and that perception is perfectly objective and omniscient. The final lines of 'The Sea Speaks' (Stockenström, 2007: 18) are:
And as I comb the wind from my hair, my gulls scanning the coastline, how unshakably I know, how I don't want to know, how arbitrary and vain I refuse to acknowledge my bound closedness with you, land.

Here Grosfoguel's 'locus of enunciation' has clearly moved from the place of the supposedly objective (read white and Western) male self. But where has it shifted to? Who is the poem's speaking 'I'? Is this the poet? Is she ventriloquising or channelling the ocean? It is possible to understand the poem as another example of a Westernised subject appropriating the subjectivity of an/Other in a colonial manner. Stockenström's audacity in imaginatively placing herself in the position of the sea is complex. The image of the sea 'comb[ing] the wind from my hair' transforms the anthropomorphic Western myths of mermaids combing their hair in submarine palaces. The sea in Stockenström's poem is a woman, but not a human one: her hair and arms span continents and her eyes ('my gulls') are separate from her physical being. This modifies the poet's subjectivity by assuming a speaking position that is at least half mythic.

The voice in 'The Sea Speaks' does not objectify the sea, but tries to understand it. It comes close to the ocean, but insists on the difference between the water and the human, thus speaking nearby. The sea is imagined as wrestling with its ambiguously dependent relationship with the land. The sea knows 'unshakably' but refuse[s] to acknowledge' its 'bound closedness' with the land. Water and land, two elements that appear to be mutually exclusive, are shown, in a neat reversal of opposition, to be 'bound' to one another. The sea's denial of its existence as interwoven with solid land, while simultaneously knowing it 'unshakably', is characteristic of Stockenström's poetic of muddling and muddying boundaries.

In 'Koichab's Water,' Stockenström again genders water as feminine. Koichab is a stream in the Namib Desert - one of the driest places on earth - which runs dry in the dunes. Water is enormously precious in these circumstances, and Stockenström's speaker uses it reverentially, recognising that it is 'Seven thousand years' 6 accumulated softness' (2007: 37). The poem remarks on the irony of using water for domestic purposes

$$
\text { (...) for the daily }
$$

chore of washing nylons and drip-dry things;

Then to the kitchen to move pots and pans about and pour water on sticky crusts.

${ }^{6}$ Aquifers in Namibia are estimated to be 'tens of thousands of years' old (Christelis and Struckmeier, 2011: 11). 
The poem's final stanza bears witness to the many social uses of water:

with its matchless whiteness to purify

and refresh and humbly become part

of brandy and water, of waste, and sewage:

a woman of noble disposition

giving herself, simply, without asking.

Despite Andries Bezuidenhout's (2009) belief that the poem is 'cynical', these lines encode powerful reverence for the element's life-giving qualities. At the same time, the poem foregrounds the degrading aspects of human-nature interactions (cf. Landwehr 1987: 45). In a posthumanist vein, the stanza upends human-centred philosophies and human exceptionalism by celebrating the water's 'matchless whiteness' ${ }^{7}$ and 'noble disposition' over the humans who thoughtlessly use it for degraded human processes. Stockenström's act of gendering the water as 'a woman' links this element to the traditionally female qualities of nurturing, mutability and self-sacrifice, while also implicitly recognising that women take on most of the quotidian chores in households.

A later poem, 'Evaporating' (Stockenström, 2007: 38), reflects on water as constitutive of selfhood. As the poet/speaker ages, her body loses water and becomes 'more brittle.' This contrasts with her childhood when

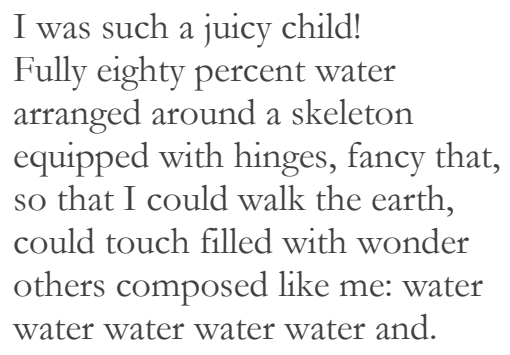

The poem articulates a deep recognition of the centrality of water and social connection in human experience. As a child, the poet/speaker 'could touch (...)/ others composed like me' of mostly water, with a small amount of other chemicals represented by 'and' at the end of the poem. 'Evaporating' does not bemoan the ageing process: rather, it celebrates the watery embodiment that links humans and non-human nature. Stockenström's poetry articulates a relational ontology, with water as a connecting medium, and 'Evaporating,' like other poems in The Wisdom of Water, insist on the entanglement of human and material. The companion poem, 'River Tidings,' which follows 'Evaporating,' metaphorically presents the poet/speaker's life as a river. Upon reaching the estuary that will flow into the sea, she feels that she has reached home and is able to

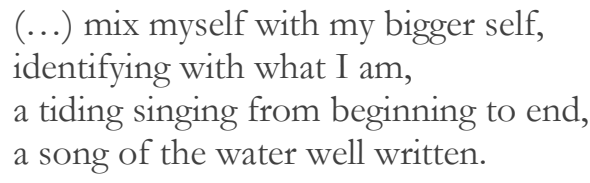

(Stockenström, 2007: 39)

These lines contain several paradoxes, which cluster around the dialectic between the 'self' and the 'bigger self. The individual self loses its contours in the 'bigger self,' and subjectivity is dissolved. The sea is an archetype of Kristeva's 'potential infinity', which contains infinite potential for signifying actions. The self in 'River Tidings' is not a unitary, Modernist-style self, which would most likely be male. This would not sit well with Stockenström's feminist aesthetic, based on an understanding of the self as always under erasure, mutable, porous and flowing. 'Tiding' in the poem's penultimate line combines the meanings of the tides of the ocean and the word's archaic meaning as news. The poem's innovation is to represent the poet/speaker as destined to 'mix myself with my bigger self (Stockenström, 2007: 39) instead of a unitary Modernist subject. She ebbs and flows together with the sea's movement in a ceaseless process of becoming. The poem harks back to 'Evaporating', where Stockenström foregrounds life's dependency on and imbrication with water. In 'River Tidings,' though, the self is a musical movement, ebbing and flowing. In this way the poem avoids the humanist vision of 'Man (...) as "the measure of all things"' (Braidotti, 2013: 13) and creates an understanding of the human as part of a "bigger self that is unmistakably ecological. The lyrically described stages followed by Stockenström's watery 'self in 'River Tidings' are reminiscent of water activist Vandana Shiva's (2008: 500) poetic description of the water cycle:

\footnotetext{
${ }^{7}$ This is less a racial reference than a comment on the water's purity, although the town of Lüderitz, which is supplied with water by this aquifer, was named after German colonists.
} 
The water cycle is the process through which water recycles itself. Water can never run out as long as it is allowed to recycle itself. As long as the forests evaporate the water, [it] moves up into the clouds, forms precipitation, falls as snow, falls as rain, comes back to the ground, the ground welcomes those raindrops, welcomes the snow and in that welcoming, recharges the aquifers, realizes the rivers. That perennial reach out of water is the water cycle, the most efficient way of renewing water resources on the planet.

Shiva cautions, however, that misusing water can limit the supply of fresh water to the point where - despite water's capacity to give itself 'simply, without asking' (Stockenström, 2007: 37) - the water cycle may be compromised and human communities run out of water. Although Stockenström does not share Shiva's activist agenda, her recognition of water as a 'bigger self' gestures towards a posthumanist relativising of human exceptionalism, insisting on humanity as part of a larger system and co-emergent with nonhuman nature.

A more recent poem by Pieter Odendaal (2018: 36), 'eersterivier' ('first river') concludes with the lines:

hoor die rivier die rivier was eerste hier
sy dra die stories van geslagte
ons verledes skuim oor klippe
ons is altyd onderweg
eendag keer ons terug see toe
dan herinner ons die golwe
aan die swaartekrag wat alle strome
laat vervloei tot rivier

hoor die rivier die rivier was eerste hier

(hear the river the river was here first

she carries generations' stories

our pasts foam over stones

we are always in process

one day we will return to the sea

then we will remind the waves

of the gravity that brings all streams

into rivers

hear the river the river was here first)

Odendaal's poem shares numerous themes and strategies with Stockenström's 'River Tidings' and 'The Sea Speaks'. Both poets use the female pronoun to refer to bodies of water, and - more importantly - they both deploy the ocean as a symbol for death and dissolution of individuality. Discrete human subjects, Stockenström and Odendaal suggest, proceed in an almost circular motion, returning to what was 'here first': water.

The poem 'River-Bank Musings' (Stockenström, 2007: 69) depicts thought as carried by water in the same way as 'River Tidings' figures the self as water:
Wonder, my own self, carries
a thought like a leaf on a pool.
The river-mouth grins wide and water sunlight-sweet flows into the seas, to the sky, choppy and jubilant.
All that way the thought goes.

Here, again, Stockenström depicts the ocean as a larger, and equally sentient, version of the self. The faculty of 'wonder' is seen here as a watery form of transport for thinking and substitutes for the traditional unitary knowing subject. The pool of wonder, in turn, is overshadowed by 'the seas' with their elemental freight of sunlight, water and sky. These material aspects of nonhuman nature are far from being a mere backdrop for the poet's reflections. Stockenström does not reflect much at all as a mirror would, despite one of her collections being titled Spiëel van Water (Mirror of Water, 1973). The surface on which her poetic images appear is far from being as smooth and unobtrusive as a mirror. Her aesthetic is closer to diffraction than to reflection in its insistence on differences rather than on sameness (cf. Barad, 2007: 71). Her consistent gendering of water as female and women as watery 
allows her to articulate a sophisticated feminist poetic response to this element that fits in well with calls, inspired by the Anthropocene, for human values and human beings to be decentred in favour of nonhuman nature.

\section{OF WATER AND LOVE: GABEBA BADEROON}

Gabeba Baderoon divides her time between the two continents of Africa and North America. Born in South Africa, she holds an academic position at Pennsylvania State University. On a visit to her country of origin, she experienced the ravages of the three-year drought that almost reduced Cape Town to a desert. Her poem 'NotYou' (Baderoon, 2018: 61) brings together the ecological and personal aspects of water in a drought:

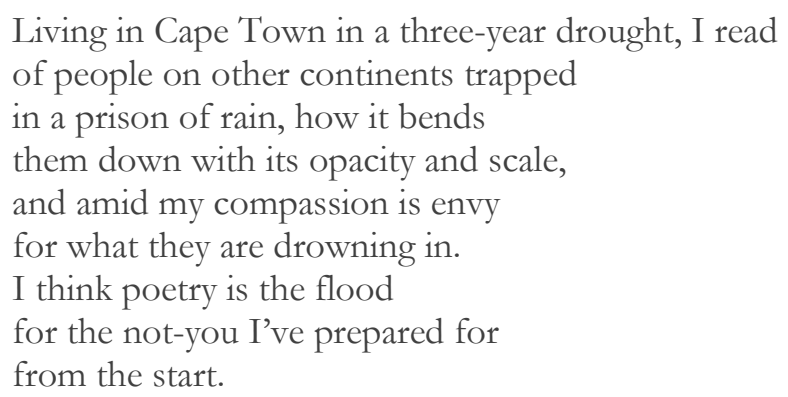

The drought lasted from 2015-2017 and was part of a devastating El Niño phenomenon caused by human actions, which have brought about climate change, population growth and other damaging environmental effects. It brought environmental degradation in the Anthropocene into sharp focus. Decision-makers in the city and the province investigated a range of solutions, including desalinating ocean water, evacuating parts of the city, throttling the water supply for agriculture and imposing harsh fines on heavy water users. These measures, together with smaller initiatives like 'dirty shirt challenges' in corporate environments to see who could wear their work shirts for the longest time before washing them, highlight what Jepson et al. (2017: 2) call 'the hydro-social relation', which is their term for the interaction of water and human beings. Baderoon describes how she ${ }^{8}$ reads of people on other continents (such as, perhaps, the other continent where she lives) 'trapped / in a prison of rain'. This may refer to the South Asian floods in 2017, which affected an estimated 45 million people, as the monsoon season brought unprecedented rainfall and widespread destruction of property, homes, lives and livelihoods. The 'prison of rain' captures how too much rain can limit people's movements and activities in the same way as Cape Town's drought impinged on social existence. The Anthropocene marks the irreversibility of human impacts on natural systems, but extreme weather systems also have irreversible effects on human beings. The 'scale' of the floods highlights the might of water and the drama of meteorological unpredictability. Baderoon highlights the entanglement of the social with the personal when she writes of her 'envy' for 'what they are drowning in' and a wish that some of the bounty of water in South Asia could be experienced in Cape Town.

The last three lines of the poem turn away from the alarming events of the Anthropocene and towards the personal resonances of water. Baderoon metaphorically equates poetry with a flood that will, in some imagined future, rescue her if she should lose her partner. This flood will possess the same dangerous 'opacity and scale' as its meteorological counterparts; and like them, it will wash away distinctions, returning the poet to Kristeva's undifferentiated pre-linguistic semiotic chora, which Johanne Prud'homme and Lyne Légaré (2006) describe as 'an infinite potential for creating signifying movements', an apt description of poetic language. Baderoon's 'flood' of poetry will, despite its capacity for destroying the structures of the psyche, bring rescue, nurturing and generation after emotional deprivation. The oppositions in these lines - drought/flood; abundance/loss; communal/personal - reinforce the polysemy of water as well as its importance in a variety of contexts.

\section{CONCLUSION}

Water is a recurrent trope in Southern African art and literature, where its deployment becomes more urgent because of its scarcity in the sub-continent. Artists, theorists and authors frequently gender water as female: a reciprocal connection, since women are often depicted as watery. This article has examined representations of water in poetry by contemporary South African women poets: Allison Claire Hoskins, Toni Stuart, Koleka Putuma, Wilma Stockenström and Gabeba Baderoon. Their poetry about water illustrates the intriguing diversity of artistic responses to water. While some poets (Stuart, Stockenström and Baderoon) portray water as agentive in its intra-

${ }^{8}$ The correspondences between Baderoon's biography and her poetry are close enough to warrant identifying the speaker in the poems as the poet herself. 
actions with human and nonhuman nature, others (Hoskins and Putuma) do not. Hoskins, Stuart and Putuma use water to symbolise the suppressed historical links between indigenous Africans and nature, as well as the transgenerational pain and trauma of colonisation. Although we are living in an era - the Anthropocene - that has brought unprecedented environmental change and degradation, surprisingly, only Baderoon engages with climate change in her poetry about water. Stockenström's poetry, written along the lines of traditional nature poetry, creatively and diffractively entangles her self and womanhood with water. She accords recognition to the water cycle and its crucial role in human affairs, but also perceives agency and materiality in water and especially the ocean. Carefully avoiding anthropomorphising the sea, she 'speaks nearby' (Chen, 1992: 87), stressing the coconstitution and co-emergence of human and oceanic being. Water as relationship (Jepson et al., 2017) features strongly in all the poems I have examined here. It connects history to the present; human beings to nonhuman nature; and it links aspects of the psyche to one another. As fresh water becomes scarcer and more highly valued in the Anthropocene, we can expect to see more poems exploring the valences of this protean and constantly selfrenewing element.

\section{REFERENCES}

Alaimo, S. (2008). Ecofeminism without Nature? Questioning the Relation between Feminism and Environmentalism. International Feminist Journal of Politics, 10(3), 299-304. https://doi.org/10.1080/14616740802185551

Baderoon, G. (2018). The History of Intimacy. Cape Town: Kwela Books.

Barad, K. (2003). Posthuman Performativity: Towards an Understanding of How Matter Comes to Matter. Signs: Journal of Women in Society and Culture, 28(3), 801-831. https:/ / doi.org/10.1086/345321

Barad, K. (2007). Meeting the Universe Halfway: Quantum physics and the entanglement of matter and meaning. Durham, NC: Duke University Press. https:/ / doi.org/10.1215/9780822388128

Bezuidenhout, A. (2009). Bleek Berus: One F Music se Mediaverklaring. Versindaba. Available at https://versindaba.co.za/2009/10/26/bleek-berus-one-f-music-se-mediaverklaring/. (Accessed 12 March 2020).

Braidotti, R. (2013). The Posthuman. Cambridge, UK: Polity Press.

Burger, B. (2020). 'Our Respect for Water is what You have Termed Fear': The Ocean in the Poetry of Ronelda S. Kamfer and Koleka Putuma. Journal of Southern African Studies, 46(1), 23-38. https://doi.org/10.1080/03057070.2020.1697552

Chen, N. (1992). 'Speaking Nearby': A conversation with Trinh T. Minh-Ha. Visual Anthropology Review, 8(1), 8291. https:// doi.org/10.1525/var.1992.8.1.82

Christelis, G. and Struckmeier, W. (eds). (2011). Groundwater in Namibia: An explanation to the hydrogeological map (2 ${ }^{\text {nd }}$ Ed.). Ministry of Agriculture, Water and Rural Development. Available at http://www.bgr.bund.de/EN/Themen/Wasser/Projekte/abgeschlossen/TZ/Namibia/groundwater_namibi a.pdf?_blob=publicationFile. (Accessed 15 March, 2020).

D’Abdon, R. (2018). 'You Say "Performance Poet", I Hear "Dance Nigger, Dance": Problematizing the notion of performance poetry in South Africa. English Studies in Africa, 61(2), 49-62. https://doi.org/10.1080/00138398.2018.1540154

De Kock, L. (2006). Blanc de Blanc: Whiteness Studies - A South African connection. Journal of Literary Studies, 22(1-2), 175-189. https://doi.org/10.1080/02564710608530396

Fanon, F. (1986). Black Skin, White Masks. Translated by Charles Lam Markmann. London: Pluto Press.

Grosfoguel, R. (2006). World-Systems Analysis in the Context of Transmodernity, Border Thinking, and Global Modernity. Review: Fernand Braudel Center, 29(2), 167-187.

Hickey-Moodey, A. and Page, T. (eds). (2015). Arts, Pedagogy, and Cultural Resistance: New materialisms. Washington DC: Rowman \& Littlefield International.

Hoskins, A-C. (2018). We are Coming for Everything. Available at https://www.youtube.com/watch?v=FFZSTVmDUcU. (Accessed 28 February 2020).

Jepson, W., Budds, J., Eichelberger, L., Harris, L., Norman, E., O'Reilly, K., Pearson, A., Shah, S., Shinn, J., Staddon, C., Stoler, J., Wutich, A. and Young, S. (2017). Advancing Human Capabilities for Water Security: A Relational Approach. https://doi.org/10.1016/j.wasec.2017.07.001

Kress, G. (2010). Multimodality: A social semiotic approach to contemporary communication. London and New York: Routledge. https://doi.org/10.4324/9780203970034

Kristeva, J. (1985). Stabat Mater. Translated by Goldhammer, Arthur. Poetics Today, 6(1/2), 133-152. https://doi.org/10.2307/1772126

Kristeva, J. (1998). Towards a Semiology of Paragrams. In P. Ffrench and R. F. Lack (eds), Tel Quel Reader (pp. 2549). London and New York: Routledge. 
Landwehr, S. L. (1987). Die Korrelasie teen Prosodie en Tematiek in die Poësie van Wilma Stockenström. Unpublished MA dissertation: University of Johannesburg. Available at: https://ujdigispace.uj.ac.za/. (Accessed 10 February 2020).

Maldonado-Torres, N. (2007). On the Coloniality of Being: Contributions to the development of a concept. Cultural Studies, 21(2-3), 240-270. https:// doi.org/10.1080/09502380601162548

Metelerkamp, J. (2019). Making Way: Poems. Cape Town: Modjaji Books.

Meyer, M. L. (2005). Thicker than Water: The origins of blood as symbol and ritual. New York and London: Routledge.

Mignolo, W. (2007). Delinking: The Rhetoric of Modernity, the Logic of Coloniality and the Grammar of DeColoniality. Cultural Studies, 21(2-3), 449-514. https://doi.org/10.1080/09502380601162647

Ndlovu, M. (2020). Poems for the Start of the World. Instagram Live, 26 September. Available at https://www.youtube.com/watch?v=FFZSTVmDUcU. (Accessed 20 January 2020).

Odendaal, P. (2018). asof geen berge ooit hier gewoon het nie. Cape Town: Tafelberg.

Parikka, J. (2015). A Geology of Media. Minneapolis and London: University of Minnesota Press. https://doi.org/10.5749/minnesota/9780816695515.001.0001

Prud'homme, J. and Légaré, L. (2006). The Subject in Process. Signo Online, directed by Louis Hébert. Quebec: Rimouski. Available at http://www.signosemio.com/kristeva/subject-in-process.asp. (Accessed 8 March 2020).

Putuma, K. (2017). Collective Amnesia. Cape Town: uHlanga.

Sharpe, C. (2016). In the Wake: On blackness and being. Durham and London: Duke University Press. https://doi.org/10.1515/9780822373452

Shiva, V. (2008). From Water Crisis to Water Culture: Dr Vandana Shiva in an interview with Andy Opel. Cultural Studies, 22(3-4), 498-509. https:/ / doi.org/10.1080/09502380802012591

Shiva, V. (2015). Water Wars: Privatization, pollution and profit. Delhi: India Research Press.

Stein, P. (2008). Multimodal Pedagogies in Diverse Classrooms: Representation, rights and resources. London and New York: Routledge. https://doi.org/10.4324/9780203935804

Stockenström, W. (1973). Spië̈l van Water. Cape Town: Human \& Rousseau.

Stockenström, W. (2007). The Wisdom of Water. Translated by Johann de Lange. Cape Town and Pretoria: Human \& Rousseau.

Stuart, T. (2018). Krotoa Eva Speaks - a Cape Jazz Poem in Three Movements. Available at https://www.youtube.com/watch?v=XjmkMCRh3g8\&feature=emb_logo. (Accessed 17 October 2020).

Wood, F. (2000). The Snake in the Sky: Tornadoes in Clay and Local Narrative in the Hogsback-Alice area. Critical Arts, 14(2), 79-95. https://doi.org/10.1080/02560040085310101

Citation: Byrne, D. C. (2021). Water in the Anthropocene: Perspectives on Poetry by South African Women. Feminist Encounters: A Journal of Critical Studies in Culture and Politics, 5(1), 07. https:/ / doi.org/10.20897/ femenc/9744 